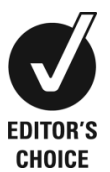

CHOICE

\title{
Everolimus-associated stomatitis in a patient who had renal transplant
}

\author{
Yisi D Ji, ${ }^{1}$ Ali Aboalela, ${ }^{2}$ Alessandro Villa ${ }^{3}$
}

${ }^{1}$ Harvard School of Dental Medicine, Boston,

Massachusetts, USA

${ }^{2}$ Ministry of National Guard Health Affairs, Riyadh, Saudi Arabia

${ }^{3}$ Department of Oral Medicine and Dentistry, Brigham and

Women's Hospital, Boston,

Massachusetts, USA

\section{Correspondence to}

Yisi D Ji, yisi_ji@hsdm.harvard. edu

Accepted 5 October 2016

\section{SUMMARY}

Everolimus is used as an immunosuppressant in renal allograft transplant rejection and in metastatic breast cancer treatment. One side effect of everolimus is stomatitis, referred to as mammalian target of rapamycin inhibitor-associated stomatitis. This side effect can affect treatment course and contribute to discontinuation of therapy or dose reduction, previously reported in the treatment of metastatic breast cancer. Here, we present a case of everolimus-associated stomatitis with a novel management method with intralesional triamcinolone that allows for continuous course of everolimus.

\section{BACKGROUND}

Everolimus is a mammalian target of rapamycin (mTOR) inhibitor derived from sirolimus, originally produced by Streptomyces hygroscopicus. ${ }^{1}$ Everolimus reduces the activity of mTOR by binding to FK-binding protein, thereby preventing cell cycle progression and proliferation. ${ }^{1}$ Everolimus is an FDA-approved agent for advanced breast cancer and pancreatic neuroendocrine tumours. ${ }^{2}$ It is also used as an immunosuppressant in renal allograft transplant rejection. ${ }^{3}$ Preclinical models show that everolimus prevents acute rejection of kidney transplants and reduces rejection. ${ }^{4}$ Vascular remodelling in transplant allografts is suggested to be part of graft dysfunction. ${ }^{4}$ Everolimus prevents this process from occurring by inhibiting smooth muscle cell proliferation and reducing intimal thickening process. ${ }^{4}$

One of the side effect of everolimus, and other mTOR inhibitors, is oral stomatitis. ${ }^{5}$ mTOR inhibitor-associated stomatitis (mIAS) can significantly affect the treatment course and may contribute to discontinuation of therapy. ${ }^{6}$ mIAS has been reported to range from $43 \%$ to $70 \% .^{5} 78$ Other side effects of everolimus include nasopharyngitis, shortness of breath and acne-like lesions. ${ }^{7}$ de Oliveira et $a l^{6}$ describe a case series revealing five patients required discontinuation of treatment due to stomatitis and five patients required dose reductions of everolimus secondary to stomatitis in the course of their cancer treatment. Reduction in dose or discontinuation of everolimus may compromise optimal outcomes, such as graft survival in patients who had renal transplants. ${ }^{9}$ Everolimus is used in renal transplant to prevent graft rejection and is associated with a lower risk of cytomegalovirus infections compared to rapamycin or sirolimus, a common concern in patients who had transplants. ${ }^{9}$
Everolimus can be used in renal allograft transplantations. $^{3}$ This requires new approaches to address everolimus-associated stomatitis. ${ }^{9}{ }^{10}$ Here, we describe a useful management strategy for symptomatic treatment and prophylaxis of mIAS in a patient who had renal transplant.

\section{CASE PRESENTATION}

A 48-year-old female was referred to the Division of Oral Medicine and Dentistry at Brigham and Women's Hospital for 'painful oral swelling'. The patient presented with persistent pain in the lower mandibular region and tongue for 5 days. Medications at time of the Oral Medicine consult included everolimus $0.75 \mathrm{mg}$ two times per day, metoprolol $25 \mathrm{mg}$ two times per day, methylprednisolone $4 \mathrm{mg}$ once daily, valganciclovir $900 \mathrm{mg}$ two times per day and ergocalciferol 50000 units once weekly. Her medical history was significant for hypertension, anaemia, hyperlipidaemia and endstage renal disease secondary to polycystic kidney disease. The patient underwent a renal transplant from a living unrelated donor 364 days prior. The donor was cytomegalovirus (CMV)-positive and the recipient was CMV-negative. Throughout the entire postoperative course, the patient was leucopenic. Prophylactic valganciclovir was discontinued 6 months after transplantation to improve the leucocyte count. Forty-five days after discontinuing valganciclovir, the patient developed CMV viraemia and CMV colitis. The patient was switched to everolimus $0.75 \mathrm{mg}$ two times per day from tacrolimus $4.5 \mathrm{mg}$ two times per day that the patient had been on since the transplant, because of potential anti-CMV effects of everolimus. ${ }^{11} 12$ The patient developed discomfort on the right mandibular area for 42 days after starting everolimus. At the time of the visit, everolimus was therapeutic at $6.1 \mathrm{ng} / \mathrm{mL}$

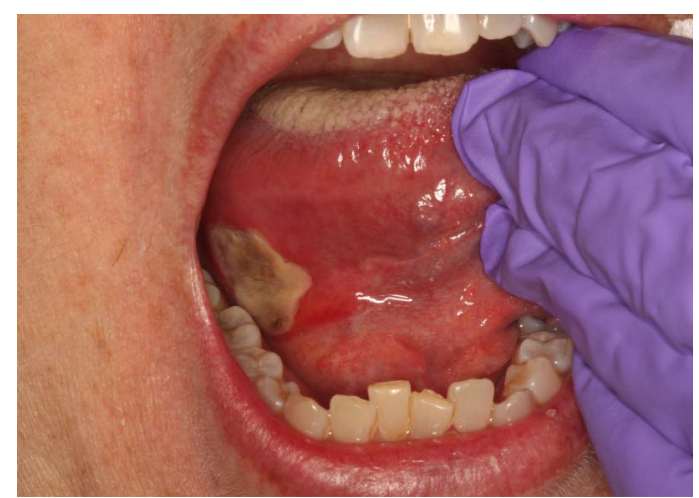

Figure 1 Everolimus-associated stomatitis. 
Table 1 Cases of mIAS secondary to everolimus use that describes management strategies

\begin{tabular}{|c|c|c|c|c|c|c|c|}
\hline Author (year) & Type of article & Disease & mTOR & Dosage & Intervention & Duration & Discussion \\
\hline $\begin{array}{l}\text { Kalogirou et al } l^{13} \\
\text { (2014) }\end{array}$ & Case series & Renal cell carcinoma and breast cancer & Everolimus & $\begin{array}{l}5 \mathrm{mg} \mathrm{qd} \\
10 \mathrm{mg} \mathrm{qd}\end{array}$ & Magic Mouthwash* four times daily & $3-15$ days & mIAS healed in 3-15 days. \\
\hline $\begin{array}{l}\text { Nicolatou-Galitis } \\
\text { et al }{ }^{15}(2013)\end{array}$ & Case series & HER2+ breast cancer & Everolimus & $10 \mathrm{mg}$ qd & $\begin{array}{l}\text { Dexamethasone solution } 0.5 \mathrm{mg} / \mathrm{mL} \text { and } \\
\text { miconazole } 2 \% \text { gel }(1-2 \text { weeks), four } \\
\text { patients discontinued everolimus }\end{array}$ & $1-2$ weeks & $\begin{array}{l}\text { Ulcers healed within 1-2 weeks of either } \\
\text { discontinuing everolimus or treatment with } \\
\text { dexamethasone solution and miconazole gel }\end{array}$ \\
\hline $\begin{array}{l}\text { de Oliveira et al }{ }^{6} \\
\text { (2011) }\end{array}$ & Case series & $\begin{array}{l}\text { Cervical chordoma, leiomyosarcoma, } \\
\text { osteosarcoma, spindle cell sarcoma, } \\
\text { liposarcoma, merkel cell carcinoma, } \\
\text { thyroid carcinoma, Waldenstrom } \\
\text { macroglobulinaemia }\end{array}$ & $\begin{array}{l}\text { Everolimus } \\
\text { Ridaforolimus }\end{array}$ & $\begin{array}{l}10 \mathrm{mg} \\
12.5 \mathrm{mg} \\
40 \mathrm{mg}\end{array}$ & $\begin{array}{l}\text { Topical anaesthetics, Magic Mouthwasht, } \\
\text { clobetasol gel } 0.05 \% \text {, dexamethasone } \\
0.1 \mathrm{mg} / \mathrm{mL} \text {, triamcinolone paste, } \\
\text { intralesional triamcinolone, systemic } \\
\text { prednisone ( } 1 \mathrm{mg} / \mathrm{kg} \text { for } 7 \text { days) }\end{array}$ & Variable & $\begin{array}{l}\text { Median time to onset of ulcers was } 10 \text { days. One of } \\
17 \text { patients discontinued therapy due to mIAS. Five of } \\
17 \text { had dose reductions due to mIAS. }\end{array}$ \\
\hline Ferté et al ${ }^{17}$ (2011) & Chart review & $\begin{array}{l}\text { Non-small-cell lung cancer, small-cell lung } \\
\text { cancer or breast cancer }\end{array}$ & Everolimus & $\begin{array}{l}\text { Ranged from } \\
2.5 \mathrm{mg} \text { qd to } \\
10 \mathrm{mg} \text { qd, or } \\
20 \mathrm{mg} \text { qw to } \\
30 \mathrm{mg} \text { qw }\end{array}$ & $\begin{array}{l}\text { Sodium bicarbonate-based mouthwash, } \\
\text { oral fluconazole }\end{array}$ & Variable & $\begin{array}{l}\text { Patients with prior chemotherapy or receiving higher } \\
\text { doses of everolimus had higher rates of ulcers and for } \\
\text { longer durations. Ten per cent of patients required } \\
\text { dose delay because of mIAS and } 9 \% \text { required dose } \\
\text { reduction due to mIAS. Empirical treatment with } \\
\text { sodium bicarbonate-based mouthwash, oral } \\
\text { fluconazole, did not show improvement in mIAS } \\
\text { within } 5 \text { days after onset. }\end{array}$ \\
\hline $\begin{array}{l}\text { Sahin et } a l^{18} \\
\text { (2011) }\end{array}$ & $\begin{array}{l}\text { Retrospective } \\
\text { chart review }\end{array}$ & $\begin{array}{l}\text { Patients who had renal transplant } \\
\text { switched from calcineurin-based therapies } \\
\text { to sirolimus or everolimus }\end{array}$ & $\begin{array}{l}\text { Sirolimus } \\
\text { Everolimus }\end{array}$ & NA & NA & NA & $\begin{array}{l}\text { Reducing calcineurin inhibitor-based therapy, } \\
\text { switching to sirolimus or everolimus, was beneficial } \\
\text { for GFR }\end{array}$ \\
\hline $\begin{array}{l}\text { Vermeulen et a } /^{19} \\
\text { (2010) }\end{array}$ & Case report & $\begin{array}{l}\text { Severe stomatitis in a patient who had } \\
\text { cardiac transplant after switching to } \\
\text { everolimus }\end{array}$ & Everolimus & & Local anaesthetic & $\begin{array}{l}\text { Not } \\
\text { specified }\end{array}$ & $\begin{array}{l}\text { Oral local anaesthetics used but no effect on } \\
\text { aphthous ulcers; required discontinuing everolimus } \\
\text { secondary to } \mathrm{mIAS} \text {, requiring conversion to } \\
\text { cyclosporine and azathioprine }\end{array}$ \\
\hline $\begin{array}{l}\text { De Simone et a }{ }^{20} \\
(2009)\end{array}$ & Prospective & 40 patients who had renal transplants & Everolimus & $0.75 \mathrm{mg} \mathrm{BID}$ & NA & NA & $\begin{array}{l}\text { Everolimus can be used in place of a calcineurin } \\
\text { inhibitor-based therapy in patients with liver allograft } \\
\text { without a decrease in efficacy. }\end{array}$ \\
\hline Ram et $a l^{21}$ (2008) & Case report & $\begin{array}{l}\text { Patients who had renal transplant on } \\
\text { sirolimus switched to everolimus }\end{array}$ & Everolimus & $0.75 \mathrm{mg} \mathrm{BID}$ & Sirolimus switched to everolimus & & $\begin{array}{l}\text { Patient developed aphthous ulcers on sirolimus and } \\
\text { then switched to everolimus. Aphthous ulcers } \\
\text { subsequently resolved. }\end{array}$ \\
\hline $\begin{array}{l}\text { Peterson et a }{ }^{22} \\
\text { (2016) }\end{array}$ & $\begin{array}{l}\text { Literature } \\
\text { review }\end{array}$ & NA & $\begin{array}{l}\text { Everolimus } \\
\text { Temsirolimus } \\
\text { Ridaforolimus } \\
\text { Sirolimus }\end{array}$ & NA & $\begin{array}{l}\text { Preventative steroid mouth rinses } \\
\text { (NCT02069093) }\end{array}$ & NA & $\begin{array}{l}\text { mIAS can affect the delivery of mTOR inhibitor } \\
\text { therapy. }\end{array}$ \\
\hline $\begin{array}{l}\text { Boers-Doets et al }{ }^{14} \\
\text { (2013) }\end{array}$ & $\begin{array}{l}\text { Literature } \\
\text { review }\end{array}$ & NA & $\begin{array}{l}\text { mTOR } \\
\text { inhibitors }\end{array}$ & NA & NA & NA & $\begin{array}{l}\text { mIAS are frequent side effects in patients with cancer } \\
\text { with genes playing a potential role. }\end{array}$ \\
\hline
\end{tabular}

${ }^{*}$ Magic Mouthwash (lidocaine gel $2 \% \times 30 \mathrm{~g}$, doxycycline suspension $50 \mathrm{mg} / 5 \mathrm{~mL} \times 60 \mathrm{~mL}$ and sucralfate oral suspension $1000 \mathrm{mg} / 5 \mathrm{~mL}$ dissolved in sodium chloride $0.9 \% \times 2000 \mathrm{~mL}$ ). ${ }^{13}$

${ }^{\dagger}$ Magic Mouthwash (lidocaine, aluminium hydroxide, magnesium hydroxide, dimethicone suspension, diphenhydramine, equal parts).

BID, two times a day; GFR, glomerular filtration rate; HER2, human estrogen receptor 2; mIAS, mTOR inhibitor-associated stomatitis; mTOR, mammalian target of rapamycin; qd, four times a day; qw, every week. 
(range $3-8 \mathrm{ng} / \mathrm{mL}$ ). The patient denied fever or malaise and reported four small raised areas on the right aspect of the tongue. The patient described a constant aching pain and a 5/10 burning sensation which increased to $7 / 10$ when swallowing. The intraoral examination revealed a $3 \mathrm{~cm} \times 3 \mathrm{~cm}$ aphthous-like ulcer with erythematous borders of the right posterior ventral tongue (figure 1). There was a slight right submandibular swelling with pain on palpation. Differential diagnosis included neutropenic ulcer, herpes simplex virus (HSV)-associated ulcer and mTOR inhibitor-associated ulcer. At the time of the first consult, the patient was leucopenic and thrombocytopenic (WCC: $0.71 \mathrm{~K} / \mu \mathrm{L}$, platelets: $63 \mathrm{~K} / \mu \mathrm{L}$ ). The patient remained leucopenic throughout the course of the development of these ulcers. Prior to starting everolimus, the patient did not develop any ulcers. A diagnosis of mIAS was made based on timeline of starting everolimus and clinical presentation of the ulcer consistent with the diagnosis. The ulcer was injected with $32 \mathrm{mg}$ of triamcinolone, and the patient was prescribed clobetasol $0.05 \%$ gel to apply to affected areas three times daily and benzocaine gel as needed for pain. A 29-gauge needle was inserted into the lesion and aspirating prior to injection of triamcinolone to ensure avoidance of any arteries. Triamcinolone $(32 \mathrm{mg}$ ) was then injected into the lesion. 0.1$0.2 \mathrm{~mL}$ is injected per square centimetre of involved mucosa. On 2-week follow-up, the patient reported 95\% improvement in symptoms and used the clobetasol $0.05 \%$ gel as directed. One hundred and eighty-one days after follow-up, the patient reported that the prophylactic clobetasol gel continues to offer tremendous relief in preventing the ulcers.

\section{OUTCOME AND FOLLOW-UP}

This case report outlines an effective management therapy for mIAS in a patient with renal allograft. The patient presented with a constellation of symptoms that can be mistaken for strep throat, an HSV ulcer or neutropenic ulcer. Here, we suggest intralesional steroid injections and topical steroid applications as an effective therapy for management of everolimus-associated oral ulcers. Management of everolimus-associated ulcers requires an interdisciplinary approach involving transplantation medicine, oral medicine and nephrology to provide optimal outcomes.

\section{DISCUSSION}

\section{Summary of results and diagnosis}

This case report highlights management strategies of mIAS in a patient with a history of renal transplant. The patient presented with a large aphthous-like ulcer on the right tongue that was successfully managed with intralesional triamcinolone $0.05 \%$ and topical clobetasol gel $0.05 \%$ with reduction in pain. mIAS presents as oral ulcerations characterised by a greyish-white pseudomembrane that are distinct from chemotherapy-associated mucositis (figure 1). ${ }^{6}$ The size and clinical presentation of the ulcer on the tongue was suggestive of an mTOR inhibitorassociated ulcer secondary to everolimus use. It is less likely that it was a neutropenic ulcer as the patient was leucopenic throughout postoperative course and did not present with ulcers prior to starting everolimus.

While there are no definitive data suggesting mIAS, the timeline and clinical presentation with history are congruent with the diagnosis of mIAS. Treatment was based empirically on clinical presentation and onset. It is possible that the combination of leucopenia and mTOR inhibitor use contributed to the development of these lesions.

Stomatitis is a known adverse effect of mTOR inhibitors, which was initially reported in the EXIST-1, RADIANT-3 and
BOLERO-2 trials. ${ }^{8}$ A meta-analysis of the incidence of stomatitis with everolimus use reveals a rate of $67 \%$ in solid tumour trials and $70 \%$ in tuberous sclerosis trials. ${ }^{8}$ Stomatitis did not affect progression-free survival. ${ }^{8}$ Of note, oncological dosing of everolimus is often multiple-fold higher than transplant dosing of everolimus; therefore, these rates are not necessarily reflective of stomatitis rates in patients who had transplants. ${ }^{8} 13$ Previous literature suggests that dose reductions were required in patients with cancer for grade 2 and 3 stomatitis, with one patient discontinuing cancer treatment. ${ }^{6}$ Literature has suggested that most cases of mIAS are generally mild and self-limiting, not requiring any treatment. ${ }^{14}$ As we cannot determine which lesions will be self-limiting, the quality of life leading to this determination can be poor, leading to complications such as malnutrition and dose reduction of medically necessary treatment. The method we present here allows for prevention of complications early on. It will be up to the providers' best judgement whether intervening with a corticosteroid injection would be beneficial to the patient as there are no predictor tools that can be used to determine which patients will develop large and painful lesions. ${ }^{14}$ Therefore, the provider must elicit the patient's input regarding pain and treatment of these lesions.

This is the first case of mIAS in a patient who had renal transplant. Previous case reports of mIAS have been reported in patients receiving high doses of everolimus for cancer treatment or liver transplants. ${ }^{15} 16$ Case series have described management of mIAS with Magic Mouthwash with the lesions resolving in 3-15 days in patients with renal cell carcinoma and breast cancer. ${ }^{13}$ Dexamethasone solution $0.5 \mathrm{mg} / \mathrm{mL}$ added to $6 \mathrm{~mL}$ of water three to four times/day with miconazole gel have been used in patients receiving everolimus for breast cancer with variable improvement in 1-2 weeks. ${ }^{15}$ Table 1 describes the various management strategies attempted to treat mIAS in the literature. There is variability in response to these treatments, with corticosteroids and local analgesics being a common management strategy. ${ }^{6-22}$ In these case reports, everolimus dosing was reduced to ameliorate the adverse effects. In the population of renal allograft, this may not be a desirable option as it increases the risk of transplant rejection. In our case, $40 \mathrm{mg}$ of intralesional triamcinolone was effective and the everolimus dose was not adjusted.

\section{Learning points}

- Intralesional triamcinolone offers relief for everolimus-associated stomatitis.

- Topical clobetasol gel $0.05 \%$ can be applied to affected areas for potential prophylaxis and alleviation of symptoms.

- This combination treatment allowed for continuation of everolimus treatment without dose reduction secondary to stomatitis.

Acknowledgements The authors acknowledge the Department of Oral Medicine and Dentistry.

Contributors YDJ wrote the manuscript and did the literature review. AV and AA saw the patient, treated the patient and edited the manuscript.

Competing interests None declared.

Patient consent Obtained.

Provenance and peer review Not commissioned; externally peer reviewed. 


\section{REFERENCES}

1 Hardinger KL, Koch MJ, Brennan DC. Current and future immunosuppressive strategies in renal transplantation. Pharmacotherapy 2004;24:1159-76. http://dx. doi.org/10.1592/phco.24.13.1159.38094

2 Baselga J, Campone M, Piccart M, et al. Everolimus in postmenopausal hormone-receptor-positive advanced breast cancer. N Engl J Med 2012;366:520-9.

3 Pascual J. The use of everolimus in renal-transplant patients. Int J Nephrol Renov Dis 2009;2:9-21.

4 Neumayer $\mathrm{H}-\mathrm{H}$. Introducing everolimus (Certican) in organ transplantation: an overview of preclinical and early clinical developments. Transplantation 2005;79(9 Suppl):S72-75.

5 Franz DN, Belousova E, Sparagana S, et al. Efficacy and safety of everolimus for subependymal giant cell astrocytomas associated with tuberous sclerosis complex (EXIST-1): a multicentre, randomised, placebo-controlled phase 3 trial. Lancet 2013;381:125-32.

6 de Oliveira MA, Martins E Martins F, et al. Clinical presentation and management of mTOR inhibitor-associated stomatitis. Oral Oncol 2011:47:998-1003.

7 Bissler JJ, Kingswood JC, Radzikowska E, et al. Everolimus for angiomyolipoma associated with tuberous sclerosis complex or sporadic lymphangioleiomyomatosis (EXIST-2): a multicentre, randomised, double-blind, placebo-controlled trial. Lancet 2013;381:817-24.

8 Rugo HS, Hortobagyi GN, Yao J, et al. Meta-analysis of stomatitis in clinical studies of everolimus: incidence and relationship with efficacy. Ann Oncol Off J Eur Soc Med Oncol ESMO 2016;27:519-25.

9 Radtke J, Dietze N, Spetzler VN, et al. Fewer cytomegalovirus complications after kidney transplantation by de novo use of mTOR inhibitors in comparison to mycophenolic acid. Transpl Infect Dis 2016;18:79-88.

10 Everolimus: Drug information (cited 30 Aug 2015). http://www.uptodate.com/ contents/everolimus-drug-information?source=search_result\&search=everolimus \& selectedTitle $=1 \%$ 7E109\#F7674091

11 Ghassemieh B, Ahya VN, Baz MA, et al. Decreased incidence of cytomegalovirus infection with sirolimus in a post hoc randomized, multicenter study in lung transplantation. J Heart Lung Transplant 2013;32:701-6.
12 Andrassy J, Hoffmann VS, Rentsch M, et al. Is cytomegalovirus prophylaxis dispensable in patients receiving an mTOR inhibitor-based immunosuppression? A systematic review and meta-analysis. Transplantation 2012;94:1208-17.

13 Kalogirou EM, Tosios KI, Piperi EP, et al. mTOR inhibitor-associated stomatitis (mIAS) in three patients with cancer treated with everolimus. Oral Surg Oral Med Oral Pathol Oral Radiol 2015;119:e13-19.

14 Boers-Doets CB, Raber-Durlacher JE, Treister NS, et al. Mammalian target of rapamycin inhibitor-associated stomatitis. Future Oncol 2013;9:1883-92.

15 Nicolatou-Galitis 0, Nikolaidi A, Athanassiadis I, et al. Oral ulcers in patients with advanced breast cancer receiving everolimus: a case series report on clinical presentation and management. Oral Surg Oral Med Oral Pathol Oral Radiol 2013;116:e110-116.

16 Trotter JF, Lizardo-Sanchez L. Everolimus in liver transplantation. Curr Opin Organ Transplant 2014;19:578-82.

17 Ferté C, Paci A, Zizi M, et al. Natural history, management and pharmacokinetics of everolimus-induced-oral ulcers: insights into compliance issues. Eur J Cancer 2011;47:2249-55.

18 Sahin S, Gürkan A, Uyar M, et al. Conversion to proliferation signal inhibitors-based immunosuppressive regimen in kidney transplantation: to whom and when? Transplant Proc 2011;43:837-40.

19 Vermeulen T, Rodrigus IE, Vrints CJ, et al. Severe stomatitis complicating immune-suppressive switch after cardiac transplantation. Acta Chir Belg 2010;110:339-41.

20 De Simone $\mathrm{P}$, Metselaar $\mathrm{HJ}$, Fischer $\mathrm{L}$, et al. Conversion from a calcineurin inhibitor to everolimus therapy in maintenance liver transplant recipients: a prospective, randomized, multicenter trial. Liver Transplant 2009;15:1262-9.

21 Ram R, Swarnalatha G, Neela P, et al. Sirolimus-induced aphthous ulcers which disappeared with conversion to everolimus. Saudi J Kidney Dis Transplant 2008;19:819-20.

22 Peterson DE, O'Shaughnessy JA, Rugo HS, et al. Oral mucosal injury caused by mammalian target of rapamycin inhibitors: emerging perspectives on pathobiology and impact on clinical practice. Cancer Med 2016;5:1897-907.

Copyright 2016 BMJ Publishing Group. All rights reserved. For permission to reuse any of this content visit

http://group.bmj.com/group/rights-licensing/permissions.

BMJ Case Report Fellows may re-use this article for personal use and teaching without any further permission.

Become a Fellow of BMJ Case Reports today and you can:

- Submit as many cases as you like

- Enjoy fast sympathetic peer review and rapid publication of accepted articles

- Access all the published articles

- Re-use any of the published material for personal use and teaching without further permission

For information on Institutional Fellowships contact consortiasales@bmjgroup.com

Visit casereports.bmj.com for more articles like this and to become a Fellow 